\title{
THE CONSENT DECREES IN THE BRAZILIAN CAPITAL
}

PhD Student in Business Law (State University of Rio de Janeiro). Master in Public Law (UNESA). Postgraduate in Business Law (FGV). Law Professor at Federal Fluminense University. Federal Fluminense University / State University of Rio de Janeiro, Brazil.

E-mail: viniciuschaves@gmail.com

Alexandre Folly Nogueira Sertã

Graduate in Law by Federal Fluminense University. Attourney, Brasil.

E-mail: alexandre.fsnogueira@gmail.com

Received: 2016-06-16. Accepted:2017-05-31

\begin{abstract}
Supported by literature research, document and data collection, an approach concerning the legal regulation of capital market is carried out, starting from the review of the regulatory instrument known as consent decree (settlement). Its first step aims at the clarification of general notions about the roles and segments of capital market, followed by the presentation of the fundamental principles regarding the disciplined set of legal dispositions. In the sequence, some features of the Brazilian regulatory body, the Brazilian Securities and Exchange Commission (CVM), are presented, such as its functions and powers, focusing on the exam of the regulatory provisions contained in the sanctioning administrative process (SAP). In accordance with Article $11, \S 5$ of Law $n^{0} 6.385 / 76$, the rules issued by CVM, which govern PAS both in ordinary and in summary rites, prescribe that, once the defendant is summonned, the issuing of a warning to advert about the possibility to propose a term of commitment is mandatory. The acceptance of the term and the consequent compliance to the provisions of the settlement constitute neither the confession to the facts nor the recognition of the illicit nature of investigated conduct. A total number of 405 terms were approved by the regulatory body between 2009 and
\end{abstract}


2014, which characterizes a wide use of this regulatory instrument. This present analysis concluded that, although the settleement herein presented may be recognized as an important mechanism in the context of capital market regulation, its excessive use constitutes a distortion of both its purposes and of the foundations of normative discipline of the market, and even of the set of functions assigned to CVM.

Keywords: capital market - regulation - administrative sanctioning proceedings - consent decree.

\section{INTRODUCTION}

The subject of the legal regulation of the capital market has been remarkably discussed in the past decades, both in legal and in regulatory aspects. In the regulatory aspect, the most diverse discussions have materialized, concerning the normative power of the regulatory bodies as well as its roles, forms of action and the enforcement of both the sanctioning and the surveillance functions regarding the performance of the economic agents before the markets.

In Brazil, the dealings between the regulatory body of the capital market, the Brazilian Securities and Exchange Commission (CVM) and its agents have been suffering modifications throughout the years, with a larger approximation due to the arising of features such as public hearings and the consent decree (settlement), which characterizes a larger aperture of the normative system. About the consent decree, the authority is allowed by law to even negotiate directly with the defendants, in order to lift or terminate proceedings, which constitutes an alternative reaction (execution of the consent decree) to the pure and simple enforcement of penalties (warnings, fines, suspensions, etc.) established in law.

The academy must not remain secluded from such debate, for the study of the questions to which it is directly or indirectly related is pressing. Therefore, a new and instigating line of research is inaugurated, having the consent decree as a background to subsidize innumerous theoretical and conceptual discussions, from both the point of view of the reflections concerning the convenience of the model itself as well as of the adequate form of its enforcement by the regulatory body. The specificity of the approaches and of the analysis herein find their justification in the relevance of the subject.

Therefore, the following research problem is formulated, which shall find its solution through the following question: are the legal and regulatory provisions, that allow the defendant in the Sanctioning Administrative Proceeding (SAP) to propose the consent decree, by 
themselves, justify the opportunity and convenience of CVM in the approval of substitutive agreements in an exaggerated scale?

For the purpose of orientation, the published literature concerning the general subject has been reviewed (considering its inherent interdisciplinarity) and also regarding the proposed specific cut (although subject to few researches). The investigation also counted with both legal and regulatory documental searches, as well as with the gathering, consolidation and analysis of empiric data concerning the consent decrees entered into by the Brazilian regulatory body between 2009 and 2014. The consolidated data was transformed into charts and inserted to this present work, in order to facilitate the comprehension of its readers.

The main purpose of this investigation is to perform an approach regarding the legal regulation of the capital market, based on the critical analysis of the regulatory instrument known as consent decree, in order to subsidize the building of a satisfactory answer to the research problem herein.

This present work is divided as follows: i) review of the literature concerning the roles and segments of the capital market, of the main foundation of the set of legal dispositions that rule such market, as well as of the characteristics of the brazilian regulatory body (CVM); ii) exam of the legal foundations and of the set of regulations concerning the Sanctioning Administrative Proceeding (SAP), focusing on the mechanism known as Consent Decree (Settlement); iii) gathering of empirical data regarding the Consent Decrees executed between 2009 and 2014, presenting such data through the charts herein inserted, with details concerning the amount of settlements executed each year; iv) critical analysis of the forms of use of the mechanism governed by the CVM.

\section{BRIEF NOTIONS REGARDING THE CAPITAL MARKET}

The capital market, also known as "Securities Exchange", comprehends a diversity of operations involving securities ${ }^{1}$ issued by publicly traded corporations, focusing on the financing of already existent companies and even of companies undergoing establishment, making the development of their corporate projects possible.

The market permits an environment that gathers a number of economic subjects: on one side, saving agents, with excessive resources; on the other, taking agents, needing capital; and there are also those who

1 In Brazil, there is no definition for the term securities. An illustrative list including a series of titles under a variety of natures, such as stocks, debentures, and subscription bonuses has been included in article $2^{\circ}$ of the Law n. $6.385 / 78$, which regulates the securities exchange and created the Securities Commission. 
are simply looking for an investment for their resources through the acquisition of papers, aiming at the rentability of the invested capital. Thus, the importance in the process of channeling of resources towards investments ${ }^{2}$.

The primary share market operates with the securities issued by publicly traded companies, which constitutes the offer of new papers to the investing public ${ }^{3}$. The issuing companies are also responsible for the trade of their own papers, using the product of such trade in the financing of their investments ${ }^{4}$. As stated by ELIAS and GAMA, the main role of this segment consists on fundraising for the economic agents through the issuing ${ }^{5}$ of such papers, which may be underwritten by the shareholders of the own company or publicly offered, allowing any investor to acquire them.

On the other hand, the secondary ${ }^{6}$ share market "registers only the transfer of the property of papers already acquired from the companies, thus, not impacting directly the flow of resources available for the issuing companies"7. This business segment allows the investor to convert the investment, transforming it back to money ${ }^{8}$, and thus, obtain the return of the invested capital and, consequently, imputing liquidity ${ }^{9}$ to the papers acquired in the primary market. Therefore, the

2 VASCONCELlOS, Marco Antonio Sandoval de; GARCIA, Manuel E. Fundamentos de Economia. 2. ed. São Paulo: Saraiva, 2005, p. 213.

3 KÜMPEL, Siegfried. Direito do Mercado de Capitais - do ponto de vista do direito europeu, alemão e brasileiro. Rio de Janeiro: Renovar, 2007, p. 68.

4 ASSAF NETO, Alexandre. Mercado financeiro. 11. ed. São Paulo: Atlas, 2012, p. 200.

5 The public issuing should be performed, in general, under the intermediation of the integrating institutions of the securities distribution system, known as "intermediaries", such as investment banks, brokering and distributing societies. The aforementioned process is called underwriting, usually undergoing through a pool of institutions for the operation. The participation in question is fundamental for the success of the public issuing, once such institutions directly aid the issuers in the compliance to the demands and requirements formulated by the CVM regarding the distribution offers.

6 The secondary market works mainly in the stock exchanges, market administration institutions, in which are performed the transactions involving securities. The stock exchanges integrate the securities distribution system, under the supervision of the regulatory body. Such institutions are responsible for providing an adequate environment for the performance of the securities business, in addition to acting as an auxiliary body at the monitoring of the respective members and of the securities transactions thereunder, as well as preventing the manipulation of prices and detecting unusual movements in the market, besides other functions.

7 GOULART, André Moura Cintra; LIMA, Geraldo Augusto Sampaio Franco de; GREGÓRIO, Jaime. Mercado de renda variável. In: LIMA, Iran Siqueira; LIMA, Geraldo Augusto Sampaio Franco de; PIMENTEL, Renê Coppe (Org.). Curso de mercado financeiro: tópicos especiais. São Paulo: Atlas, 2006, p. 28.

8 LAMEIRA, Valdir de Jesus. Mercado de Capitais. 2. ed. Rio de Janeiro: Forense Universitária, 2003, p. 123.

9 The liquidity is an economic concept which, in general, indicates the possibility to transform 
negotiation market is of vital importance to ensure the success of single issuing and, in a broader view, of the own primary share market.

\section{THE LAW OF THE CAPITAL MARKET}

The law of the capital market is represented by the set of legal dispositions that discipline the operations carried out in its environment. According to KÜMPEL's doctrine, three main points may be identified as the objects of regulation, being the most important the one that includes the judicial organization of certain market segments and its dispositions concerning the conditions to negotiate securities, intending to protect its functioning ability. According to the author, such branch of law belongs into the Economic Law and is penetrated by public law due to its considerable collective interest in the existence of markets as effective as possible ${ }^{10}$. Thus, two primary goals are pertinent to the regulation of the law of capital market: i) the protection of it functioning ability (priority scope); and, consequently, ii) the protection of the investor ${ }^{11}$.

The protection of the functioning ability of the market, as a legal asset to be prioritarily protected, aiming at the maximization of its efficiency, requires the taking of a number of adequate measures such as: i) institutional functioning ability (which consists on the basic conditions for the existence of a series of efficient mechanisms in the different segments of the market, through its opening in such a way that permits the access of supply and demand, and therefore, allow the the channeling of the largest possible portion of the capitals towards the market and their acquisition by the economic agents, fulfilling the financing needs of such agents. Regarding the basic legal conditions, measures taken for the preservation and enhancement of the investor's trust, which is directly related to the transparency, stability, equality in the access to data, justice and integrity of the segments of the market, which would be related to the duty of assuring isonomic treatment regarding the right to sensitive information, transparency of the shareholding structure of the companies, rules of conduct applicable to the intermediaries of the market, as well as the monitoring of the market by the government); b) operational functioning ability (related to the necessity to reduce costs for both the issuers of securities and the investors, considering that such costs impact directly on the decisions of

an asset into money. Such phenomena is one of the features that makes the capital market so attractive in the eyes of the investors, as it allows them to negotiate its ownership at any time, together with other interested investors. The higher the easiness of negotiation of a certain asset in market price, the higher its liquidity.

10 KÜMPEL, op. cit., p. 4-8.

11 Ibid, p. 21-37. 
both parties. Therefore the necessity of such a drastic reduction on both the securities issuing expenses and the financial burden of the investing agents); and c) the placement functioning ability (aiming at the assuring of the fluidity of the resources/capitals, considering its scarcity, to the most relevant alternatives at the development point of view, driving the execution of social reality transforming projects.

On its turn, the protection of the investor, as an additional legal asset, would unfold in the defense, through the law of capital market: a) of the unspecific set of investors (the defense of the investing agents, both actual and future, considering that the business performance potential is of extreme importance for the liquidity of the market, with positive reflexes on its functioning ability); and b) exceptional protection of the individual concerns of the investors, through the damage reparation pretensions (legal projection on benefit of the investors, individually, in occurrence of the performed securities trading business, and not of the investor agents in general) $)^{12}$.

The law of capital market, thus, shall include rules arising out of the Legislative Power, as well as the regulatory rules created by specific bodies constituted for the exercise of specific functions in the capital market environment. In Brazil, the regulatory body of the capital market is the Brazilian Securities and Exchange Commission (CVM).

\section{BRAZILIAN SECURITIES AND EXCHANGE COMMISSION}

The Brazilian Securities and Exchange Commission, created by the Law n. $6.385 / 1976^{13}$, is a federal agency under special ${ }^{14}$ regulation

12 KÜMPEL, op. cit., p. 21-41.

13 Prior to the creation of the CVM, the Laws n. 4.595/64 and n. 4.728/65, along with the Laws n. $6.385 / 76$ and n. $6.404 / 76$ were of high importance for the structuring of the national financial system.

14 According to MOREIRA NETO, the agency may be described as "an entity of public law from the indirect administration, created by law, functionally decentralized from the State, which performs both its own and specific state attributions, doted with financial, administrative and patrimonial autonomy". The author also points out that the most important characteristic is in the specialization of such bodies and functions in order to comply to certain public interests. MOREIRA NETO, Diogo de Figueiredo. Curso de direito administrativo: parte introdutória, parte geral e parte especial. $11^{\mathrm{a}}$ ed.,rev. e atual. Rio de Janeiro: Forense, 1998, p. 186. The phrase special regime agency, adverts GASPARINI, does not find its legal concept in the law, and the doctrine has been attempting to outline it from the legal regime of the agency, once it possess "larger privileges than the normal agencies". GASPARINI, Diógenes. Direito Administrativo. $14^{\mathrm{a}}$ ed. rev. São Paulo: Saraiva, 2009, p. 327. According to NAZAR, "the special regime agencies are those to which the creating law grants specific privileges and increases its autonomy if compared to the other agencies, without damaging the constitutional precepts". NAZAR, Nelson. Direito econômico. 
that answers to the Treasury Department and has legal personality and its own estate. The CVM is also doted of independent administrative authority, absence of hierarchic subordination, fixed tenure and stability of its leaders, as well as financial and budget autonomy. Until its constitution, there was not any specific entity to absorb the regulation and monitoring of the capital market ${ }^{15}$, being such functions, a burden of the Central Bank of Brazil ${ }^{16}$.

Its condition of specially regulated agency, it is important to point out, was effective only after the issuing of the Provisional Measure n. 8, converted into the Law n. 10.411/2002, which gave the entity the status of Regulatory Agency ${ }^{17}$. Until that given moment, it was not uncommon to find in the doctrine authors who would deny such nature ${ }^{18}$.

As of the imputation of such inherent characteristics to CVM, the treatment given should be proportional to said nature, specially in connection with the possibility of issuing of regulatory dispositions concerning the securities exchange market in Brazil. Hence, through the exam of articles $3^{\text {rd }}, 4^{\text {th }}$ and $5^{\text {th }}$ of the Law n. $6.385 / 1976$, KÜMPEL clarifies that the jurisdiction of CVM includes both the regulation of the securities exchange market and the permanent monitoring of the activities and of the services carried out in such segment as well as the dissemination of information concerning both the market itself and those who take part in its operations and the securities negotiated

$2^{\text {a }}$. ed. rev., ampl. e atual. Bauru: EDIPRO, 2009, p. 48.

15 FORTUNA, Eduardo. Mercado financeiro: produtos e serviços. 15. ed., rev. e atual. Rio de Janeiro: Qualitymark, 2002, p. 21.

16 As to such aspect, the interesting considerations of WHITE are assigned as: "Considering that, at that moment the securities Exchange had a relatively reduced expression, there was no intention to grant it a regulatory body of its own, so, the Central Bank, whose main attributions were the control of the means of payment and the monitoring of the banking institutions, became also entitled to the regulation of such market". WHITE, Maria Clara Isoldi. A nova constituição e a regulamentação do sistema financeiro. Revista da CVM, nº 15, jan./fev./mar. 1987, p. 23.

17 EIZIRIK, Nelson, et. al. Mercado de Capitais - regime jurídico. 3. ed. Rio de Janeiro: Renovar, 2011., p. 260.

18 Egon Bockmann Moreira, in his article published in 1999, prior to the creation of the referred law, when analysing the legal nature of the National Monetary Counsel, of the Central Bank of Brazil and of the CVM, denied them the status of regulatory agencies through the following terms: "...seems inadequate to attribute to such administrative person the title of "independent regulatory agencies", considering that the managerial and functional bond with the direct administration prevents such classification. Actually, they are not even "Administrative Agencies", but bodies that submit to the traditional concepts of deconcentration" (CMN) and "decentralisation" (BACEN and CVM)". MOREIRA, Egon Bockmann. Conselho Monetário Nacional, Banco Central do Brasil e Comissão de Valores Mobiliários. Considerações acerca de sua natureza jurídica, em face das chamadas "Agências Administrativas". Revista de Direito Mercantil, ano XXXVIII, v. 116, out./dez. São Paulo, Malheiros, 1999, p. 141-142. 
thereunder ${ }^{19}$.

Generally, the CVM, considering the purpose of its functions, shall exercise them in order to: i) ensure the efficient and regular functioning of both the securities and "over the counter" markets; ii) protect the owners of securities from the irregular issuing and illegal acts of officers or controlling shareholders from companies or securities portfolio managers; iii) prevent or forbid fraudulent practices or manipulations intended to create artificial conditions for supply, demand or for the prices of the securities traded in the market; iv) ensure the public access to information concerning the traded securities and its issuing companies; v) ensure the observance of equitable trading practices in the securities market; vi) stimulate savings and its application in securities; vii) promote the expansion and efficient and regular functioning of the stock market and stimulate the permanent applications in the capital stock of public companies ${ }^{20}$.

The CVM, created with the purpose of disciplining, monitoring and developing the capital market, has, in its regulatory function ${ }^{21}$, one of its main capacities ${ }^{22}$. Through autonomy and agility, the CVM shall

19 KÜMPEL, op. cit., p. 249.

20 CVM. Available at: <http://www.cvm.gov.br>. Access: July 25, 2015.

21 In the doctrine it is possible to find authors that regard the difference between ruling and regulation. In this present work, the broad sense of regulation will be considered, in fact, in a wider manner, including both the ruling and the regulation in their strict sense. Regarding the subject, it is interesting to point out the position of Maria Eduarda Fleck da Rosa, to whom the capacities attributed to the CVM may be defined as hybrid, including both the ruling and the regulation. When ruling, the agency would be detailing the content of the principles and rules stipulated in Laws n. 6.385/76 and n. 6.404/76. In opposition, when regulating, would fulfil eventual gaps or omissions in such legal documents. According to the author, the regulatory power, named suplementar capacity, reveals itself in the "possibility of the CVM to integrate the legal system, in order to fulfil normative gaps arising out of new situations in the capital market, which complexity and dynamism could not be foreseen by the ordinary legislator." The author proceeds pointing out that the regulatory power "shall be exercised within the limits imposed by article 4th (of the Law \# 6.385/76, as marked) and of the Federal Constitution." ROSA, Maria Eduarda Fleck da. O Poder Normativo da Comissão de Valores Mobiliários. São Paulo, 2012, 139f. Master's dissertation (Master's Degree in Laws). Post-Graduation in Laws at the State University of São Paulo, f. 103.

22 It is important to point out the definition brought by Odete Medauar which, although signs the meaning of the term in its broadest sense, ends up listing a series of powers that are mistaken for those attirbuted to the CVM: "We understand that the regulation, in its current context, includes: the creation of norms; the fiscalization of its enforcement; the attribution of qualifications (i.e. authorization, permission, concession); the imposition of penalties; the mediation of conflicts (both to prevent and to solve, making use of a variety of technics, such as: public consultation, public hearings, execution of a compromise to cease and adjustment settlement)" MEDAUAR, Odete. Regulação e Auto Regulação. Revista de Direito Administrativo, Rio de Janeiro, nº 228, 
regulate the dynamic and complex economic and financial relations undergoing inside such environment ${ }^{23}$, guiding its activities by a set of principles based on a series of foundations, identified as key-factors for the promotion of the fundamental conditions for its expansion and development. Such purposes depend on the efficiency and trust reliability of the market, consequence of the guarantee of adequate levels of protection and harmony amongst the concerns of all the economic agents trading thereunder. Such foundations are ${ }^{24}$ :

General public interest: the transfer of resources between the investors and the economic agents is crucial for the continuous formation of capital, when contemplating a society such as the Brazilian, which clearly opted for the capitalist model, based on free enterprise and the market-oriented economy. Is through such resources transfer process that the investment and growth of the economic units is obtained and, as a consequence, of the society as a whole. Therefore, the regular functioning of the securities exchange market is of general public interest.

Reliability: the existence and the growth of the market depend on the trust that its various agents have on the system. If the purpose of the regulatory body is to favor the development of the market in such a way that it will always be able to cope with the growing demands of the society, it becomes imperative to observe said purpose. The regulation should be carried out in order to create a trustworthy foundation that shall ensure the owners of savings accounts that the trade in the market environment brings solely its own risks.

Efficiency of the market: one of the many features regarding the free market is its ability to function as a mechanism apt to direct the savings of a society towards the financial projects with the most adequacy with its expectations. This aspect has to be observed and sought during the regulatory work, considering that only through such work it is possible to best meet the needs of society. Equally, the decreasing of the costs related to

abr.jun. 2002, p. 126.

23 According to Alexandre Santos de Aragão, "the laws that grant normative power to the independent regulatory entities have low normative density, in order to provide the development of sectorial norms apt to, under autonomy and agility, rule the dynamic and complex subjacent social reality". ARAGÃO, Alexandre Santos de. O Poder Normativo das Agências Reguladoras. Revista Trimestral de Direito Público, $\mathrm{n}^{\circ}$ 36, São Paulo: Malheiros, 2001, p. 104.

24 COMISSÃO de valores mobiliários (Brasil). O Mercado de Valores Mobiliários Brasileiro. Rio de Janeiro: CVM/SOI, 2013. [on line]. Available at: <http://www.portaldoinvestidor.gov. br/portaldoinves tidor/export/sites/portaldoinvestidor/publicacao/Livro/LivroTOP-CVM.pdf>. Access in: 10 jun. 2015. 
the mediation of such resources meets both the needs of the companies and the individuals that invest on it, and it shall be through the efficiency of the market that such purposes may be achieved: locating and operating efficiencies.

Competitiveness: the efficiency of the market depends on the level of competition established among its participants. Therefore, the regulation has to maintain the attention on such fundament, not only preventing competitiveness decreasing actions, but also ensuring its health. Also, the active competition reduces the need for regulation.

Free market: the freedom of action in the market and of access to its mechanisms is a precondition of the existence of a market able to adequately perform its functions. In the process of regulation of the securities market, it is necessary the permanent presence of both the respect to the free flow of the forces of the market and the free access to the performance of the activities and to the operations thereunder.

The analysis if the abovementioned fundaments permits the conclusion that the regulatory role of the agency comprises not only one, but many objectives, which may be seen as complementary amongst themselves. Such conclusion is clear in the doctrine of CANTIDIANO ${ }^{25}$, to whom the activity of the regulatory body accommodates at least four main scopes, as described below:

The entire activity performed by the regulatory body has the finality (a) of stimulating the creation of savings and its application in securities, (b) promote and ensure the expansion and the efficient and regular functioning of the securities market, (c) protect the securities owners and the investors, against (i) the irregular issuing of securities, against (ii) illegal acts of the administrators and controllers of the companies and savings managers and and (iii) against the use of relevant information not yet divulged to the market and (d) ensure the observance of the proportionate trading practices in the market.

In order to carry out its normative, monitoring and sanctioning functions, the CVM is endowed with police power, through which it can limit the individual liberty in favor of public or collective interests. Thus, the agency has both material and institutional means

25 CANTIDIANO, Luiz Leonardo. O Papel Regulador da CVM. In: WALD, Arnoldo (Org.) Direito empresarial: mercado de capitais, v. 8. São Paulo: Revista dos Tribunais, 2011, p. 672. 
at its disposition for the regular performance of its attributions, having the responsibility, for example, to initiate sanctioning administrative proceedings ex officio.

\section{THE CONSENT DECREE IN THE SANCTIONING ADMINISTRATIVE PROCEEDING}

The fundaments and finalities of the legal discipline of the capital market point to the necessity of maintenance of an environment of respect of the legal (i.e. Laws n. 6.385/1976 and n. 6.404/1976) regulatory (i.e. normative instructions issued by $\mathrm{CVM}$ ) frameworks, as well as the proportionate practices by the administrators, fiscal counselors and shareholders of publicly traded companies, mediators and the other participants of the market.

Therefore, the Law n. 6.385/1976 endows CVM with the powerduty to apply a series of penalties to the offenders, amongst which, notices, fines, suspensions, temporary impediments and prohibitions and withdrawal. The application of such penalties occur after ascertainment and verification, via sanctioning administrative proceeding (SAP), of the violating actions in the legal, regulatory and proportionate practices frameworks. It must be pointed out that the penalization should proportionate larger educational and preventive effects for the participants of the market.

The abovementioned Law, in its article 11, §5, states that the regulatory body may, at its own discretion, if permitted by the public interest, suspend, in any stage, the administrative proceeding installed for the ascertainment of the offenses to the securities exchange market, if the investigated offender executes the CD (settlement), obliging himself to: I - stop the practice of activities or actions considered illicit by CVM; and II - correct the irregularities pointed out, including the indemnification for the damages caused.

The SAP shall observe the proceeding established by CVM itself in the exercise of its normative power. Currently, it is disciplined through Deliberation n. 538 of March $5^{\text {th }}, 2008$, with the amendments brought by Deliberation n. 552/08 (rules the ordinary proceeding), and also the Instruction n. 545/14 (rules the summary proceeding). Both disposing about the proceedings to be observed in the procedural protocol of the SAP installed by the agency.

Both in Deliberation n. 538 (art. 13, $\S 4^{\circ}$ ) and in Instruction $\mathrm{n}^{\mathrm{o}}$ 545 (Art. $2^{\circ}, \S 2^{\circ}$, inc. VI), in the citation act shall include a notice regarding the prerogative of the accused of executing a $\mathrm{CD}^{26}$, except

26 As noted by WELLISCH and SANTOS, the North American consent decree would be the main inspiration for the Brazilian version of the instrument. WELLISCH, Julya Sotto Mayor; SANTOS, Alexandre Pinheiro dos. O termo de compromisso no âmbito do mercado de valores 
in event of the ascertainment of the irregularities related to Law $n$. 9.613/98 (which regards the crimes of money laundering, concealment of assets, rights or values; the prevention of the use of the financial system for the practice of the illicit acts prescribed by this law, and creates the Financial Activities Control Counsel - FACC), as well as the cases ruled by the Instruction n. 301/99 of CVM.

The CD is ruled by the Deliberation n. 390/01 (amended by Deliberation n. 486/05), which regards the proceedings of the aforementioned institute, through Ordinances PTE n. 71/05 and PTE n. 066/08, both from CVM.

\section{DYNAMICS OF THE CONSENT DECREE}

Except when of the ascertainment of the irregularities in connection with Law n. 9.613/98 and in the event of cases ruled by Instruction n. 301/99 of CVM, the agency is authorized to execute the CD in the other installed SAP, as prescribed by art. $1^{\text {st }}, \S 1^{\text {st }}$ of the Deliberation n. 390/01 of CVM.

The interested party in the execution of the CD my present a written proposal to CVM, through which the party obliges to: i) stop the practice of activities or actions deemed illicit, if the case may be; and ii) correct the identified irregularities, including indemnification of the damages caused to the market or to CVM.

The interested party shall disclose the intention of execution of the CD until the deadline of the defense arguments, notwithstanding the burden of presenting such arguments. However, the aforementioned disclosure is also permitted in the preliminary investigation stage. In the first case, the full proposal shall be addressed to the Administrative Proceedings Control Coordination - APCC in no longer than 30 (thirty) days after the presentation of the defense. In the second case, it shall be addressed to the Superintendence responsible for the investigation.

The Federal Specialized Prosecutor's Office (FSP) of CVM shall be heard about the legality of the proposal presented by the interested party. After the manifestation of the FSP, the General Superintendent shall submit the proposal of execution of CD to the Consent Decree Committee $(\mathrm{CDC})^{27}$, which shall present its opinion (in no longer

mobiliários. Interesse Público - IP, Belo Horizonte, ano 11, n. 53, jan./fev. 2009. Besides the influence of the consent decree, noted by the two authors, it is possible to say that the consent decree, in national context, has similarities with the compromise to cease the investigated practice, present in the Antitrust Law (n. 12.529/11) and, also with the conditional suspension of the criminal proceeding, prescribed in Law n. 9.099/95.

27 The current composition of the Committee is disciplined in article 2nd of the Ordinance CVM PTE n. 71, of August, 17th, 2005, with text provided by the Ordinance CVM PTE n. 066, of April 1st, 2008. Article 2nd - The Consent Decree 
than 30 days as of the presentation of the opinion of FSP) regarding the opportunity and convenience in the execution, and de adequacy of the proposal formulated by the accused, proposing to the Body its acceptance or denial, considering the opportunity and convenience, the nature and severity of the offenses object to such proceeding, the accused records and the effective possibility of penalty, in the particular case.

Prior to the preparation of its opinions, the CDC, in its convenience, may negotiate with the proposer the most adequate conditions. Such negotiation between the CDC and the proposer shall be concluded within a maximum of 60 (sixty) days, with the possibility for the Committee to, at the end of negotiations, amend the initial proposal, if within the deadline imposed by the Committee. May this be the case, the deadline for the preparation of the opinions of the Committee be counted as of the date in which the negotiations were concluded or as of the presentation of the amendments to the initial proposal, as the case may be.

The execution proposal, together with the opinions of the CDC, shall be submitted to the deliberation of the Body, which shall come to a decision regarding its acceptance or denial. If accepted, the decree shall be entered into by the President of CVM, by the interested parties and by two witnesses.

The CD shall suspend the current administrative proceeding, for the period stipulated for the fulfillment of the settlement. On the other hand, the conditions of the decree, after accepted by the Body, shall not be amended, unless a new deliberation is carried out by request of the interested party.

The execution of the consent decree shall not imply in a confession as to the matter of fact, nor acknowledgement of illegal conduct analyzed in the proceeding that originated it, being those the most relevant advantages for the accused of illegal practices.

From the decision of the Body that denies the proposal for CD there shall be no appeals to the Resources Counsel of the National Financial System, once the discretion to accept or deny the execution of the decree is exclusively of the agency, pursuant to art. $11, \S 5^{\text {th }}$ of the Law n. 6.385/76.

\section{ANALYSIS OF THE MAIN THEORETICALAND PRACTICAL ASPECTS OF THE CONSENT DECREE}

Committee shall be comprised of the owners of the following Superintendences: I General Superintendence - GS; II - External Monitoring Superintendence - EMS; III - Corporate Relations Superintendence - CRS; IV - Market and Intermediaries Relations Superintendence - MIRS; V - Auditing and Accounting Regulations Superintendence - AARS; and VI - Sanctioning Proceedings Superintendence - SPS. 
According to SILVEIRA ${ }^{28}$, the judicial nature of the CD is approximately of the transaction, to the extent that characterizes a deal between the accused and the CVM. As a matter of fact, the settlement may be understood as legal business, considering that it combines the features from both civil transaction and discretionary ${ }^{29}$ administrative act, in which the Administration is endowed with a certain liberty to evaluate or decide.

The nature of the legal business is clear through the analysis of MUTO and $\mathrm{YOKOI}^{30}$, to whom it is a role of CVM to accept the proposed terms, deny or even discuss amends, as typical options of the agents that seek to perform legal businesses, but without the necessity of legal approval of the eventually performed decree. It is important to emphasize that the dynamics of the consent decree in the Brazilian reality is different, for example, from the one present in the American model, in which the efficiency of the consent decree depends on the judicial approval.

Through the $C D$ there is a possibility of reparation to the damaged investors, even if not parties in the proceeding. EIZIRIK ${ }^{31}$ teaches that the demand for reparation only occurs in the event of any quantifiable damage or against identifiable damaged individuals so it may be possible to attribute to each their own indemnification values. In this respect, it is duly noted that the art. 10 of the Deliberation n. $390 / 01$ prescribes that, in the event of damages to investors, there is a possibility for CVM, at its discretion, to notify such investors to present further information regarding the quantification of the value to be paid in reparation.

In abovementioned case, the damaged investor shall refrain from presenting information further than the extent of the damaged suffered and the value of reparation. Nevertheless, in the event of undetermined or unidentifiable damaged investors, the agency may, by common consent with the proposer and at his expenses, publish summons with

28 SILVEIRA, Sandra Maria Bittencourt da. O Instituto do Termo de Compromisso no Sistema de Regulação do Mercado de Capitais Brasileiro. São Paulo, 2006. Master's dissertation (Master's Degree in Laws). Post-graduation at Catholic Pontifical University - PUC. f. 35.

29 Administrative act is the unilateral declaration of the State in the exercise of public prerrogatives, expressed through complementary concrete commands of the law issued in order to enforce its fulfillment and subject to legitimacy control by the jurisdictional body. MELLO,

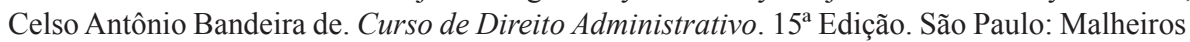
Editores 2003, p. 352.

30 MUTO, Silvio; YOKOI, Yuki. Colegiado da CVM amplia o uso de termos de compromisso. Revista Capital Aberto, ed. 60, 2008. Available at: <http://www. capitalaberto.com.br/temas/ colegiado-da-cvm-amplia-uso-de-termos-de-compromisso/\#.VZxPO 1K4JMp>. Access in: 07 jul. 2015.

31 EIZIRIK, Nelson et. al. Mercado de Capitais - regime jurídico. 3. ed. Rio de Janeiro: Renovar, 2011, p. 359. 
the purpose of determining and identifying such damaged investors as well as to reach the quantification of the individual values to be paid as indemnification.

Until 2006, emphasizes SILVEIRA ${ }^{32}$, the main obligations imposed to the proposers in the accepted consent decrees were: donations to charitable institutions, recomposing of data to the damaged investors along with the costs incurred by CVM in connection with the administrative proceeding, implementation of internal negotiations policy in trading securities with publicly traded companies, performance of trainings and seminars and distribution of materials regarding applicable regulations, with educational scope, performance of public offering for the papers and for the acquisition of shares from the minority shareholders that do not adhere to the public offering.

As to the enforcement, the CVM may carry out the judicial enforcing of the decree, which is a extrajudicial executable title, pursuant to article $11, \S 7^{\text {th }}$ of the Law n. $6.385 / 76$, together with the restart of the sanctioning administrative proceeding, suspended by occurrence of the settlement. Such conduct is not considered bis in idem, once the consent decree does not apply penalties, but imposes obligations ${ }^{33}$.

Prior to its amendments by Law n. 10.303/01, the final part of the $\S 7^{\text {th }}$ of the article 11 of Law n. $6.385 / 76$ prescribed that the non fulfillment of the consent decree implies in contempt, pursuant to article 330 of the Criminal Code. The doctrine criticized such paragraph. According to EIZIRIK $^{34}$, the crime was not configured, once no orders were issued by CVM as of the execution of the consent decree. Considering the negotiating nature of the decree, there is no order, but solely a simple agreement.

Another important question, emphasized by SILVEIRA ${ }^{35}$ is that the non compliance of the consent decree may not be considered as an aggravating circumstance by CVM in the application of penalties if the accused, by non complying with the settlement, is condemned in the sanctioning administrative proceeding. The claim is that the settlement solely imposes the suspension of the SAP installed against the accused, therefore, the penalization of the accused, after the ascertainment of the illegality of the practices pointed out by CVM as infractions, could not be aggravated by the non compliance of the decree.

Once there is a confirmation that the settlement entered into by CVM and the accused arised out of a legal defect, thus not brought by

32 SILVEIRA, op. cit., p. 79.

33 MORAES, Luiza Rangel de. Considerações sobre o consent decree e sua aplicação no âmbito da disciplina do mercado de valores mobiliários. Revista de Direito Bancário e do Mercado de Capitais, São Paulo, nº 4, jul-set, 1998, p. 40.

34 EIZIRIK, op. cit., p. 273.

35 SILVEIRA, op. cit., p. 14. 
convenience and opportunity criteria, an interested party may request in court the deconstruction of the consent decree executed through judicial ruling. However, the deconstruction based on legal defect does not ban the possibility to execute a new decree, free from defects ${ }^{36}$.

Throughout the years, the modalities of obligations assumed by the consenting parties has been altered. In the beginning, the obligation leaned towards the offering of seminars or to elaborate educational material to be distributed amongst the investors. Since the year 2000, in many consent decrees contained the obligation of donation to social programs and philantropic entities has been noted. In 2005, there was an increase in the attributions of values to CVM as a form of compensation for expenses, donations, fines, and damage repair caused to the agency or the the capital market. After 2006, the obligation to pay a determined amount to CVM, without specification of the reason, became more frequently noted ${ }^{37}$.

Such as prescribed by the relevant legislation, the CVM may reject the proposal of consent decrees. In the year 2005 a data survey regarding the enquiries to determine the reasons that lead CVM to reject or accept the consent decree was carried out, concluding as follows: in the event of approval of the proposal to a consent decree by CVM, such decision was based mainly on the presence of the convenience and opportunity features, with emphasis on the compensation for the damages as a determinant factor for the acceptance of such decree. On the other hand, in the event of rejection of the proposal, the decision was based mainly on the absence of both the aforementioned features and of the compensation for the caused damages and in the event of undertaking of a commitment related to the supposed irregular practice as of the execution of the decree, considering that such practice is already mandatory by the regulation itself $\mathrm{f}^{38}$.

On January, $15^{\text {th }}, 2009$, a research contemplating 184 consent decrees entered into and settled by the CVM between the years 1998 and 2008 was published, exposing the enhancing level of compliance to the obligations therein. Only one non-compliance was detected (IA CVM n. 04 of 1999), in which, according to TANJI ${ }^{39}$, was followed by a: "(i) ruling by the body of CVM with the application of administrative penalties, (ii) promotion of public action by the Federal Public Ministry in face of the promissory parties, in which the CVM acted as assistant

36 Ibid., p. 62.

37 TANJI, Márcia. Mercado de capitais brasileiro e tutela coletiva dos interesses. São Paulo, 2009, p. 102. Master's dissertation (Master's Degree in Laws). Post-graduation in Laws at the State University of São Paulo - USP.

38 SILVEIRA, op. cit., p. 87.

39 TANJI, op. cit., p. 101. 
to the accusation" 40 .

In practice, many consent decrees have a high money value, nevertheless, there are defendants that, even aware of their innocence, choose to execute the decree and pay, maintaining their good reputations, once the pending administrative matters represents an obstacle to good business opportunities, and even more, preferring to prevent the risks of conviction" ${ }^{41}$. It must be noted that as "to the values owed to the damaged, those who suffered the damages arising out of the conduct of the promising party, a relevant value is perceived, but still lower than the one owed to the CVM"42.

In an interesting exercise of application of the thesis/antithesis methodology, the magazine Capital Aberto published two opinion articles, in which the authors were proposed to face the following question: Are the consent decrees being used too largely by the CVM?

According to CHAVES, the decrees have been too largely used by the agency, which reflects the need of more thoroughness in the approval of the settlements. In the opinion of the author, in severe cases, as in the event of the practice of improper use of relevant information, there should be no possibility of executing a consent decree. In opposition, AMENDOLARA denies the excessive use, as far as it represents an effective instrument which, in practice, prevents law suits that ore often dragged through long periods and show no guarantee of conviction to the damaging parties ${ }^{43}$.

\section{THE CONSENT DECREE IN THE PERIOD BETWEEN 2009 AND 2014: TRIVIALIZATION OF THE USE OF THE REGULATORY INSTRUMENT?}

The methodological option for the performance of research about empirical data regarding the aforementioned instrument was made in order to achieve a better evaluation of the $\mathrm{CD}$ as a regulatory instrument in the Brazilian capital market.

Considering the need of a cut, the period between 2009 and

40 Process n. 2004.61.00.019427-5 processed at the 5th Federal Civil Court of the Judiciary Subsection of the Capitol of the State of São Paulo.

41 CARRION, Bruna Maia. Por que os cada vez mais milionários termos de compromisso se tornaram uma saída conveniente para a CVM e para os acusados. Revista Capital Aberto, ed. 91, mar. 2011, s/p. Available at: <http://www.capitalaberto.com.br/temas/ calculo-de-risco/\#. VZxO4FK4JMp>. Access in: 06 jul. 2015.

42 TANJI, op. cit., p. 102.

43 CHAVES, Renato. É preciso mais rigor; AMENDOLARA, Leslie. Instituto eficaz. Revista Capital Aberto, ed. 78, fev. 2010, p. 46-47. Available at: <http://www.capitalaberto.com.br/ pageflip/78/Ed\%2078/assets/basic-html/page46.html>. Access in: 06 ago. 2015. 
2014 was more profoundly analyzed, even though the instrument has been used since 1998 (which is, just the year after its introduction to the legal system in 1997). In a further analysis, approaches were found in the doctrine regarding the subject, which, majorly indexed information concerning concrete data related to the period prior to 2009 . Therefore, the proposed cut would allow a more updated view of the recent dynamics of the use of such instrument.

In that vein, the CD approved in the years 2009, 2010, 2011, 2012, 2013 and 2014 were obtained through research at the CVM files. It is important to highlight that: i) there are cases in which the settlements "approved" in a given year are only executed in the following year, giving reason to the option for the counting of only those approved until the end of the cut; ii) in many cases, there are more than one settlement approved in connection with the same SAP.

The obtained data was consolidated and transferred to the two following graphics, which, according to the adopted methodology, show the annual quantity of settlements approved by the regulatory body in each year of the selected periods.
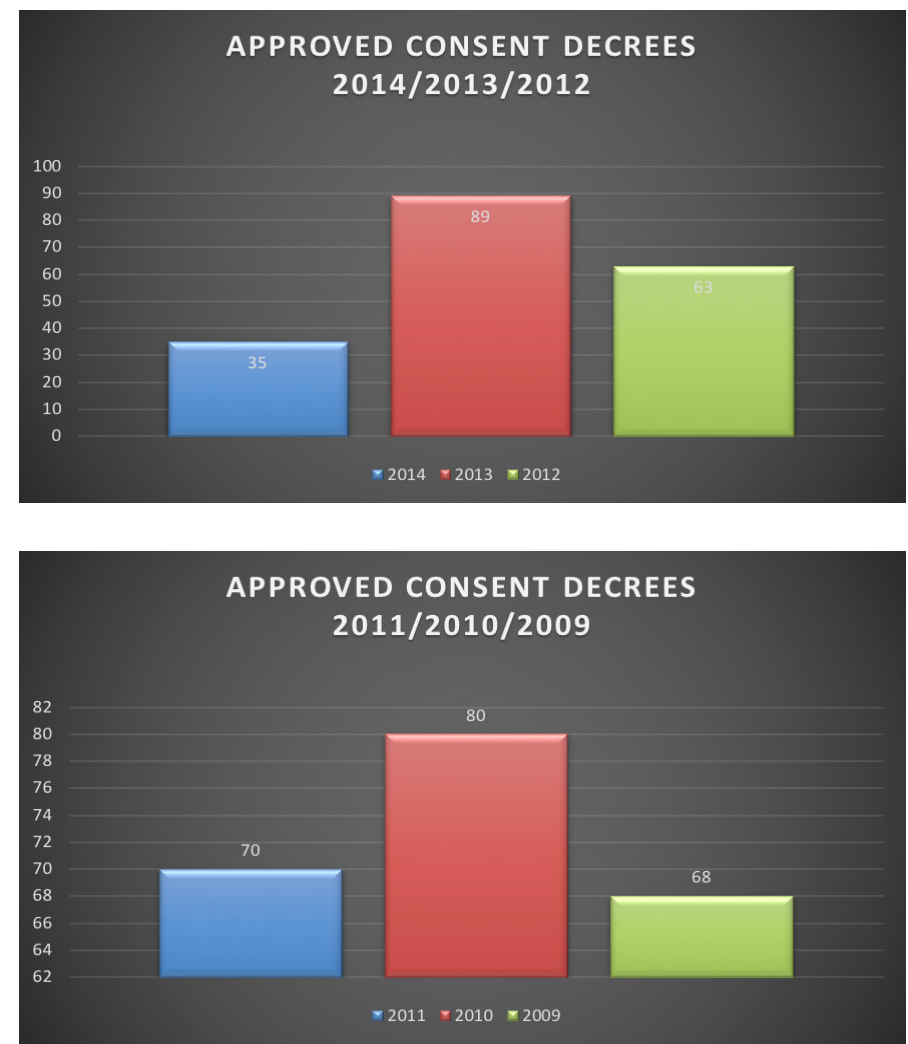
It is noticeable, considering the consolidated data in the graphics, the excessive utilization, by the CVM, of the permission to execute the settlement together with the offenders of both the legal and regulatory frameworks and also of the equality of the practices carried out in the capital market, as an alternative answer to the application of the penalties prescribed in the Law n. 6.385/76. It is registered that were also observed cases in which the settlement propositions were rejected by the agency ${ }^{44}$.

The data indicate that, although the settlement may be understood as an important mechanism in the field of capital market regulation since it characterizes a larger aperture of the normative system to the market agents and ensures space to the alternative reactions to the pure and simple application of penalties, allowing the negotiations to be carried out between the agency and the defendants, in order to suspend or terminate law suits, fixate indemnifications, etc. - its excessive use implies a distortion of its finalities, of the fundaments of the normative discipline of the market and of the set of functions assigned to CVM.

The CD should not be vulgarized ${ }^{45}$ in such a way that it constitutes a type of authorization/incentive to the practice of offenses, promoting the general knowledge that it would suffice for the offender to execute the decree, immediately after the offense, and be solely compromised to cease the practice of the activities or actions deemed illegal by CVM and correct the appointed irregularities, including compensating damages.

The confidence, one of the foundations of the regulation, indicates

44 In the analysis of the proposal for consent decree in connection with the sanctioning administrative proceeding RJ2012/9808, the body, in 01/06/2015, unanimously deliberated as inopportune e inconvenient the acceptance of the proposal, since the eventual execution of the consent decree together with the defendants would not represent a significant economy in the proceeding to the CVM, being the presented proposals rejected. Another important point: the recurrence is one of the reasons that causes CVM to refuse the proposal for consent decree, such as occurred in June, 17th, 2015, when to body unanimously decided for the rejection of the proposal for consent decree made by the Federal Government, which was accused of failure to comply with the provisions of article 115th of the Stock Corporation Law, arising out of its participation in the Extra-ordinary General Meeting that deliberated for the acceptance of the terms of the Provisional Measure 579 - which caused damages to the state company (AMEC, 2015).

45 There are two questions that may, perhaps, constitue a type of informal incentive to the use of the settlements in a larger scale: 1) the difficulty of the CVM regarding the agility in the judgement of the processes (there are processes from 2010 only now, in 2015, being judged); 2) the monetary penalties (currently, they cannot exceed the highest amongst the following values: i) $\mathrm{R} \$ 500.000,00$; ii) fifty percent of the value or the issuing or of the irregular transaction; or iii) three times the amount of the economic advantage obtained or of the loss prevented in occurrence of the illicit) prescribed in Law n.6.385/76. Although, it is believed that such factors may not be used as reasons for the distortion of the institute of the consent decree. 
that the normative discipline of the market should be carried out in order to create a relying base that assures the savings owner the certainty that he may act exclusively under the risks of the own business in which he chooses to operate. The offenses to the regulatory framework corrode the trust of the investors in the market. And a market shall never be effective if there is no reliability in its regular functioning, to which the respect for the set of the game rules is mandatory.

In the same way, the role of the CVM should be in order to discourage the illegal practices, watch the protection of the owners of securities against the irregular issuing and illegal acts from the administrators and controlling shareholders or even securities portfolio managers; avoid or prevent fraud modalities or manipulations intended to create artificial conditions of demand, supply or price of the securities traded in the market; ensure the access to the public to the information regarding the traded securities and the issuing companies in connection to such securities; ensure the observance of the equal trading practices in the securities market; stimulate the creation of savings and its application in securities; promote the expansion and the efficient functioning of the stock market and stimulate the permanent applications in the shares of the capital stock of the publicly traded companies.

It must be reminded that, if at the application of penalties for the practice of actions that offend the legal and regulatory framework or the equal practices, the penalization should provide a larger educational and preventive effect to the agents of the market (intending to prevent future illegal practices), it is possible that, through the excessive use of the settlement, generate an exactly opposing effect, or else, the dissemination of the idea that the offending actions and unequal practices may be "erased" through the execution of a consent decree. Such possible negative effect is helped by the own legal discipline of the subject, which indicates that the settlement, if proposed, accepted and complied to, shall not constitute a confession as to the matter of fact, nor a recognition of the illegality of the analyzed conduct.

\section{CONCLUSIONS}

From the present research, the comprehension of the CD as an important regulatory mechanism to be used by the regulatory body of the Brazilian capital market, the CVM, was possible.

Through such instrument, the agency may enter into settlements together with the offenders of the legal and regulatory frameworks, or with the responsible for the performance of unequal practices in the market scope. The decrees constitute a possibility to an alternative reaction to the penalties prescribed in the Law n. 6.385/76, distinguishing 
an open normative system that allows a higher approximation between the regulatory body and the market agents.

As an answer to the research problem that oriented this present investigation, it is believed that the previsions in both the legal and regulatory scopes, which contemplate the possibility for the defendant, in the sanctioning administrative proceeding context, to propose the execution of the consent decree, do not make, by themselves, opportune and convenient the excessive execution of the decrees.

Considering its nature of regulatory instrument, its use should be restricted to the foundations that inspire the regulatory framework, such as public interest, reliability and efficiency of the market. In the same way, those who use it, in this case the CVM, should be limited by the respect for the institutional finalities of the decree, such as the protection of the owners of securities, prevention or prohibition of fraud or manipulation types, ensuring of the observance of the equal trading practices in the securities market, stimulation of the creation of savings and its application in securities, promoting the expansion and the regular and efficient functioning of the market and stimulating the permanent application in the shares of the capital stock from the publicly traded companies.

By the examination of the SAP installed between 2009 and 2014, a final number of 405 decrees approved by the regulatory body was reached, a result that characterizes an increasing utilization of this regulatory instrument. The excessive use of the alternative reaction to the penalties is believed to implicate in a distortion of the finalities of the own settlement as a mechanism of regulation, as well as a violation of the foundations of the normative discipline of the market itself and of the set of functions assigned to CVM.

Therefore, the use of the CD must be restricted to punctual cases, which configures a public interest in the alternative reaction to the application of the penalties prescribed in the Law, considered the foundations of the regulation and the finalities of the CVM itself. In this vein, it is emphasized a possible directive for the role of the agency, as an incentive to new settlement models: i) as a general rule, the use must be restricted to the cases prescribed in the Instruction CVM n. 545/14, which applies the SAP in its summary rite, for the ascertainment of the possible objective offenses, related to an omissive conduct of the market agents; ii) exceptionally and under a higher thoroughness, the use in the event of certain generally light offenses (which application would obey the Deliberation CVM n. 538/08, which regulates the SAP in its ordinary rite), being forbid in grave cases such as the irregular use of relevant information. 


\section{REFERENCES}

AMEC. CVM rejeita por unanimidade Termo de Compromisso da União no Caso Eletrobrás. Available at: <http://www.amecbrasil.org. br>. Access: July 12, 2015.

ARAGÃO, Alexandre Santos de. O Poder Normativo das Agências Reguladoras. Revista Trimestral de Direito Público, no 36. São Paulo: Malheiros, 2001.

ASSAF NETO, Alexandre. Mercado financeiro. 11. ed. São Paulo: Atlas, 2012.

CANTIDIANO, Luiz Leonardo. O Papel Regulador da CVM. In: WALD, Arnoldo (Org.) Direito empresarial: mercado de capitais, v. 8. São Paulo: Revista dos Tribunais, 2011.

CARRION, Bruna Maia. Por que os cada vez mais milionários termos de compromisso se tornaram uma saída conveniente para a CVM e para os acusados. Revista Capital Aberto, ed. 91., mar. 2011. Available at: http:// www.capitalaberto.com.br/temas/ calculo-de-risco/\#.VZxO4FK4JMp. Access: July 06, 2015.

CHAVES, Renato. É preciso mais rigor; AMENDOLARA, Leslie. Instituto eficaz. Revista Capital Aberto, ed. 78, fev. 2010, p. 46-47. Available at: http://www.capitalaberto.com.br/pageflip/78/Ed\%2078/ assets/basic-html/page46.html. Access: August 06, 2015.

COMISSÃO de valores mobiliários (Brasil). O Mercado de Valores Mobiliários Brasileiro. Rio de Janeiro: CVM/SOI, 2013.

COSTA, Gabriel Carvalho da; BRIGAGÃO, Pedro Henrique Castello VIEIRA, Victor da Silveira. O dever de diligência não julgado-Casos encerrados pela CVM com a celebração de termos de compromisso. Available at: http://www.puc-rio.br/pibic/relatorio_resumo2013/ relatorios_pdf/ccs/DIR/DIR-Gabriel\%20Carvalho $\% 20 \mathrm{Pedro} \%$ 20Brigag\%C3\%A3o-Mais .pdf. Access: July 13, 2015.

EIZIRIK, Nelson, et. al. Mercado de Capitais - regime jurídico. 3. ed. Rio de Janeiro: Renovar, 2011.

ELIAS, Luiz Antônio Rodrigues; GAMA, Eduardo Guimarães. O mercado de ações no Brasil. In: CASTRO, Hélio Oliveira Porto Carrero de (Coord.). Introdução ao mercado de capitais. Rio de Janeiro: IBMEC, 1979.

FORTUNA, Eduardo. Mercado financeiro: produtos e serviços. 15. ed., rev. e atual. Rio de Janeiro: Qualitymark, 2002.

GASPARINI, Diógenes. Direito Administrativo. 14. ed. rev. São Paulo: 
Saraiva, 2009.

GOULART, André Moura Cintra; LIMA, Geraldo Augusto Sampaio Franco de; GREGÓRIO, Jaime. Mercado de renda variável. In: LIMA, Iran Siqueira; LIMA, Geraldo Augusto Sampaio Franco de; PIMENTEL, Renê Coppe (Org.). Curso de mercado financeiro: tópicos especiais. São Paulo: Atlas, 2006.

GUERREIRO, José Alexandre Tavares. Sobre o Poder Disciplinar da CVM. Revista de Direito Mercantil, São Paulo, vol. 43, 1981.

KÜMPEL, Siegfried. Direito do Mercado de Capitais - do ponto de vista do direito europeu, alemão e brasileiro. Rio de Janeiro: Renovar, 2007.

LAMEIRA, Valdir de Jesus. Mercado de Capitais. 2. ed. Rio de Janeiro: Forense Universitária, 2003.

MEDAUAR, Odete. Regulação e Auto Regulação. Revista de Direito Administrativo, Rio de Janeiro, $\mathrm{n}^{\mathrm{o}}$ 228, abr./jun. 2002.

MELLO, Celso Antônio Bandeira de. Curso de Direito Administrativo.

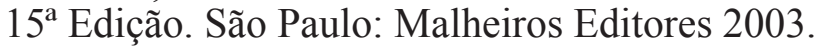

MORAES, Luiza Rangel de. Considerações sobre o consent degree e sua aplicação no âmbito da disciplina do mercado de valores mobiliários. Revista de Direito Bancário e do Mercado de Capitais, São Paulo, nº 4, jul-set, 1998.

MOREIRA, Egon Bockmann. Conselho Monetário Nacional, Banco Central do Brasil e Comissão de Valores Mobiliários. Considerações acerca de sua natureza jurídica, em face das chamadas "Agências Administrativas". Revista de Direito Mercantil, ano XXXVIII, v. 116, out./dez. São Paulo, Malheiros, 1999.

MOREIRANETO, Diogo de Figueiredo. Curso de direito administrativo: parte introdutória, parte geral e parte especial. 11. ed.,rev. e atual. Rio de Janeiro: Forense, 1998.

MUTO, Silvio; YOKOI, Yuki. Colegiado da CVM amplia o uso de termos de compromisso. Revista Capital Aberto, ed. 60, 2008. Available at: http://www. capitalaberto.com.br/temas/colegiado-da-cvm-ampliauso-de-termos-de-compromisso/\#.VZxPO 1K4JMp. Access: July 07, 2015.

NAZAR, Nelson. Direito econômico. 2. ed. rev., ampl. e atual. Bauru: EDIPRO, 2009.

RODRIGUES, Ana Carolina. A responsabilidade civil dos administradores de companhias abertas não financeiras por danos causados à sociedade e aos acionistas e o desenvolvimento do mercado 
de valores mobiliários brasileiro. São Paulo, 2011. Dissertação (Mestrado em Direito). Pós-graduação em Direito da Faculdade de Direito da Fundação Getúlio Vargas - FGV.

ROSA, Maria Eduarda Fleck da. O Poder Normativo da Comissão de Valores Mobiliários. São Paulo, 2012. Dissertação (Mestrado em Direito). Pós-Graduação em Direito da Faculdade de Direito da Universidade do Estado de São Paulo - USP.

SILVEIRA, Sandra Maria Bittencourt da. O Instituto do Termo de Compromisso no Sistema de Regulação do Mercado de Capitais Brasileiro. São Paulo, 2006. Dissertação (Mestrado em Direito). Pósgraduação em Direito da Faculdade de Direito da Pontifícia Universidade Católica - PUC.

TANJI, Márcia. Mercado de capitais brasileiro e tutela coletiva dos interesses. São Paulo, 2009. Dissertação (Mestrado em Direito). Pósgraduação em Direito da Faculdade de Direito da Universidade de São Paulo - USP.

VASCONCELLOS, Marco Antonio Sandoval de; GARCIA, Manuel E. Fundamentos de Economia. 2. ed. São Paulo: Saraiva, 2005.

WELLISCH, Julya Sotto Mayor; SANTOS, Alexandre Pinheiro dos. O termo de compromisso no âmbito do mercado de valores mobiliários. Interesse Público - IP, Belo Horizonte, ano 11, n. 53, jan./fev. 2009.

WHITE, Maria Clara Isoldi. A nova constituição e a regulamentação do sistema financeiro. Revista da CVM, nº 15, jan./fev./mar. 1987. 